\title{
High-Latitude Paleomagnetic Poles from Middle Jurassic Plutons and Moat Volcanics in New England and the Controversy Regarding Jurassic Apparent Polar Wander for North America
}

\author{
MICKEY C. VANFOSSEN AND DENNIS V. KENT
}

\author{
Lamont-Doherty Geological Observatory and Department of Geological Sciences, Columbia University \\ Palisades, New York
}

\begin{abstract}
A paleomagnetic study of Middle Jurassic plutonic and volcanic rocks in New England (White Mountains Magma Series) yields high-latitude pole positions for North America. High unblocking temperature, moderate to high coercivity magnetizations of normal polarity have been isolated in three plutons (White Mountains batholith, Mount Monadnock, and the Belknap Mountains; mean age $-169 \mathrm{Mz}$ ), but the mean pole $\left(88.4^{\circ} \mathrm{N}, 82.1^{\circ} \mathrm{E}, A 95=6.1^{\circ}\right)$ is not distinguishable from the geographic axis and therefore the hypothesis that the plutons have been contaminated by recent field overprints can not be rejected. However, a dual polarity, high unblocking temperature, and high coercivity magnetization isolated from the Moat volcanics (169 Ma, Rb-Sr age) was apparently acquired soon after caldera collapse and tilting, at about the time of intrusion and cooling of the Conway granite (reported ages K-Ar biotite, $168 \mathrm{Ma}$; zircon fission track, $163 \mathrm{Ma})$. The Moat volcanics pole position $\left(78.7^{\circ} \mathrm{N}, 90.3^{\circ} \mathrm{E}, d p=7.1^{\circ}, d m=10.2^{\circ}\right)$ calculated using the mean magnetization direction of reversed polarity (the $\mathrm{Cr}$ component) falls at high latitude but is distinguishable from the spin axis. Moreover, published Middle Jurassic paleomagnetic poles from Gondwana (Africa, Australia, and East Antarctica) transferred to the North American reference frame also suggest a high-latinde Middle Jurassic pole position for North America, in agreement with the Moat volcanics pole. The new evidence for a Middle Jurassic loop to high latitudes in the North American apparent polar wander path conflicts by $15^{\circ}-20^{\circ}$ with some key published Jurassic reference poles (e.g., the Newark Trend N2 and the Corral Canyon poles) used to constrain current paleomagnetic Euler pole (PEP) apparent polar wander paths for the Jurassic. We suggest that a plausible explanation for the discrepancy is that the N2 and Corral Canyon magnetizations are in fact secondary and were acquired after tilting. The hypothesis that the North American apparent polar wander path ventured to high latitude in the Middle Jurassic requires further testing, however the results of this study already suggest that the path may be more complicated than that proposed by recently published PEP studies.
\end{abstract}

\section{INTRODUCTION}

The paleomagnetic pole reported by Opdyke and Wensink [1966] from the White Mountains Magma Series in New England falls at $85.5^{\circ} \mathrm{N}, 126.5^{\circ} \mathrm{E}\left(A 95=5.5^{\circ}\right)$, based on 12 sites whose age was assumed to be that of the Conway granite, cited to be $180 \mathrm{Ma}$. More recently, May et al. [1986] reported a paleopole from volcanic and volcanoclastic rocks dated at 172 $\mathrm{Ma}$ from Corral Canyon in southeastern Arizona which falls at $61.8^{\circ} \mathrm{N}, 116.0^{\circ} \mathrm{E}\left(A 95=6.2^{\circ}\right)$, almost $24^{\circ}$ of arc distance from the White Mountains pole despite the similarity in apparent age of the rocks (Figure 1). The discordance between the White Mountains and Corral Canyon paleopoles highlights a major difference in some recently published interpretations of the apparent polar wander path of North America. For example, the Irving and Irving [1982] "running mean" apparent polar wander path attains high latitudes in the Jurassic mainly because the White Mountains pole was included in this compilation, whereas the White Mountains pole grossly disagreed with the lower latitude paleomagnetic Euler pole apparent polar wander paths of.Gordon et al. [1984] and May and Butler [1986] and was excluded in these analyses.

May and Butler [1986] provide cogent reasons for regarding the White Mountains pole as unreliable, namely, the correspondence of the pole with geographic north, the lack of thermal demagnetization, and the wide age range now

Copyright 1990 by the American Geophysical Union.

Paper number 90JB01380.

$0148-0227 / 90 / 90 \mathrm{JB}-01380 \$ 05.00$ documented [e.g., Foland and Faul, 1977] for the White Mountains intrusions. In fact, three of the five plutons (constituting eight of the 12 sites) which provided what were assumed to be Jurassic paleomagnetic directions have since been dated at about $120 \mathrm{Ma}$ or Cretaceous. The four site mean directions from two confirmed Jurassic igneous units (Belknap and Mount Monadnock; sites 4, 5, 11, and 12 from Opdyke and Wensink [1966]) nevertheless are entirely of normal polarity and give a recalculated pole position at $88.4^{\circ} \mathrm{N}, 354.6^{\circ} \mathrm{E}\left(\mathrm{A}_{95}=\right.$ $3.5^{\circ}$ ), again not significantly different from geographic north.

While the suspicion of recent field contamination remains for the Jurassic igneous units of the White Mountains Magma Series, it is curious that Cretaceous and Triassic units do not appear to be similarly affected. Opdyke and Wensink [1966] already obtained, and we have confirmed [Van Fossen and Kent, 1988], stable reversed polarity magnetizations from Mount Ascutney gabbros (120 Ma) which yield a pole position consistent with Cretaceous reference poles for North America. Similarly, recent paleomagnetic results from the nearby Abbott (225 Ma) and Agamenticus (227 Ma) plutons show little evidence for present day field overprinting and are broadly consistent with Triassic paleomagnetic directions for North America [ $W u$ and Van der Voo, 1988]. The Cretaceous and Triassic results also argue against any significant post-Triassic regional tilting in New England.

In this new study of the White Mountains Magma Series, our main objective was to address the paleomagnetic stability issue, with new alternating field and thermal demagnetization experiments on a variety of Jurassic plutonic rocks as well as on Jurassic siliceous flows (Moat volcanics) in central New Hampshire. 


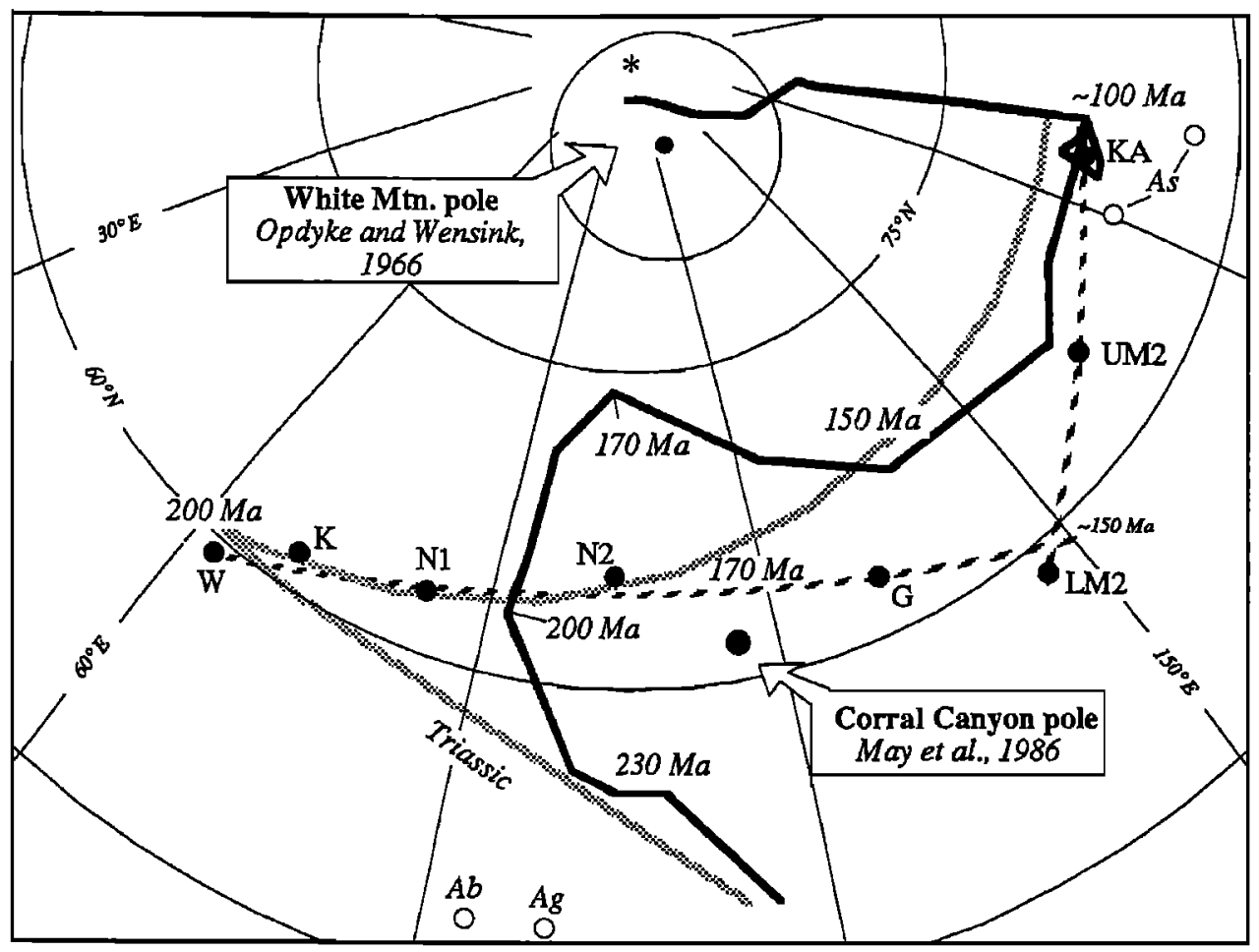

Fig. 1. Controversy in Middle Jurassic North American reference pole selection is illustrated by the discordance between two published reference poles (White Mountains pole from Opdyke and Wensink [1966] and the Corral Canyon pole from May et al. [1986]), both nominally of Middle Jurassic age but separated by about $24^{\circ}$ of arc distance. As discussed in the text, this problem contributes to different versions of the Jurassic apparent polar wander path (solid black line, Irving and Irving [1982]; light gray line, Gordon et al. [1984]; dashed line, May and Butler [1986]). Solid circles represent published North American Jurassic reference poles used by May and Butler: W, Wingate pole [Reeve, 1975]; K, Kayenta pole [Steiner and Helsley, 1974]; N1 and N2, Newark Trend 1 and 2 poles, respectively [Smith and Noltimier, 1979]; G, Glance conglomerate pole [Kluth et al., 1982]; LM2 and UM2, lower and upper Morrison formation poles using selected data [Steiner and Helsley, 1975]. Other poles (open circles): KA, mid-Cretaceous average [Mankinen, 1978]; As, Mount Ascutney [Opdyke and Wensink, 1966]; Ab and Ag. Triassic Abbott and Agamenticus plutons, respectively [Wu and Van der Voo, 1988].

\section{GEOLOGY OF THE FIELD AREAS AND PALEOMAGNETIC SAMPLING}

The White Mountains Magma Series of New England forms a 240-km-long north by northwest trending belt of approximately 30 igneous plutons, stocks, and some related volcanic flows. These alkaline rocks intrude lower to middle Paleozoic metamorphic and igneous formations and their emplacement appears to have been controlled mainly by ring fracture stoping [Chapman, 1968]. Published K-Ar and Rb-Sr age data [Foland and Faul, 1977] demonstrate that White Mountains igneous activity occurred during the Mesozoic over a period of about $135 \mathrm{~m} . y$. Furthermore, the data suggest that the magmas were injected during three distinct episodes: the first of these during the Late Triassic $(-230 \mathrm{Ma})$, a second and perhaps more extensive phase occurring in the Jurassic ( $175 \mathrm{Ma})$, followed by an Early Cretaceous phase ( $115 \mathrm{Ma})$.

Age dating studies also provide detailed thermochronometrical constraints on the Jurassic rocks of the White Mountains Magma Series. Rb-Sr biotite, $\mathrm{Pb} 206 / \mathrm{U} 238$ and $\mathrm{Pb}$ 207/U 235 ages [Tilton et al., 1957; Aldrich et al., 1958; Hurley et al., 1960] indicate that the White Mountains batholith (the largest body of the White Mountains Magma Series) crystallized about 175-180 m.y. ago. More recent Rb-Sr dating of a variety of plutonic rocks on the east side of the White Mountains batholith [Eby and Creasy, 1983] confirms that a climax in plutonic activity probably occurred there at about $175 \mathrm{Ma}$. A $168 \pm 3 \mathrm{Ma}$ K-Ar biotite age [Foland et al., 1971] on Conway granite from the eastern side of the White Mountains batholith (Figure 2) suggests that the granite cooled to $300^{\circ} \mathrm{C}$ or $350^{\circ} \mathrm{C}$ rather quickly, a conclusion supported by a zircon fission track age $(163 \pm 14 \mathrm{Ma})$ also determined on Conway granite from this region [Doherty and Lyons, 1980]. These data combined with an apatite fission track age of $94 \pm 8$ Ma may be accepted as evidence that the field area has experienced an undisturbed thermal history after initial cooling due to gradual unroofing or in any case, that the White Mountains batholith had not been heated higher than about $125^{\circ} \mathrm{C}$ since the early Late Cretaceous. Thermochronometrical data from other Jurassic plutons in New England, including those igneous units studied here (see below), support the same conclusion [Doherty and Lyons, 1980].

We sampled Jurassic plutonic rocks in three general areas: White Mountains batholith, Mount Monadnock, and the Belknap Mountains (Figure 2). Two sites of Conway granite from the White Mountains batholith have been sampled near the town of North Conway (inset, Figure 2). Five kilometers northward we have also sampled a diorite plug and the Albany quartz syenite ring dike which partially surrounds Mount Kearsage. Contact relationships suggest that the Conway granite is younger than the quartz syenite and diorite; the 


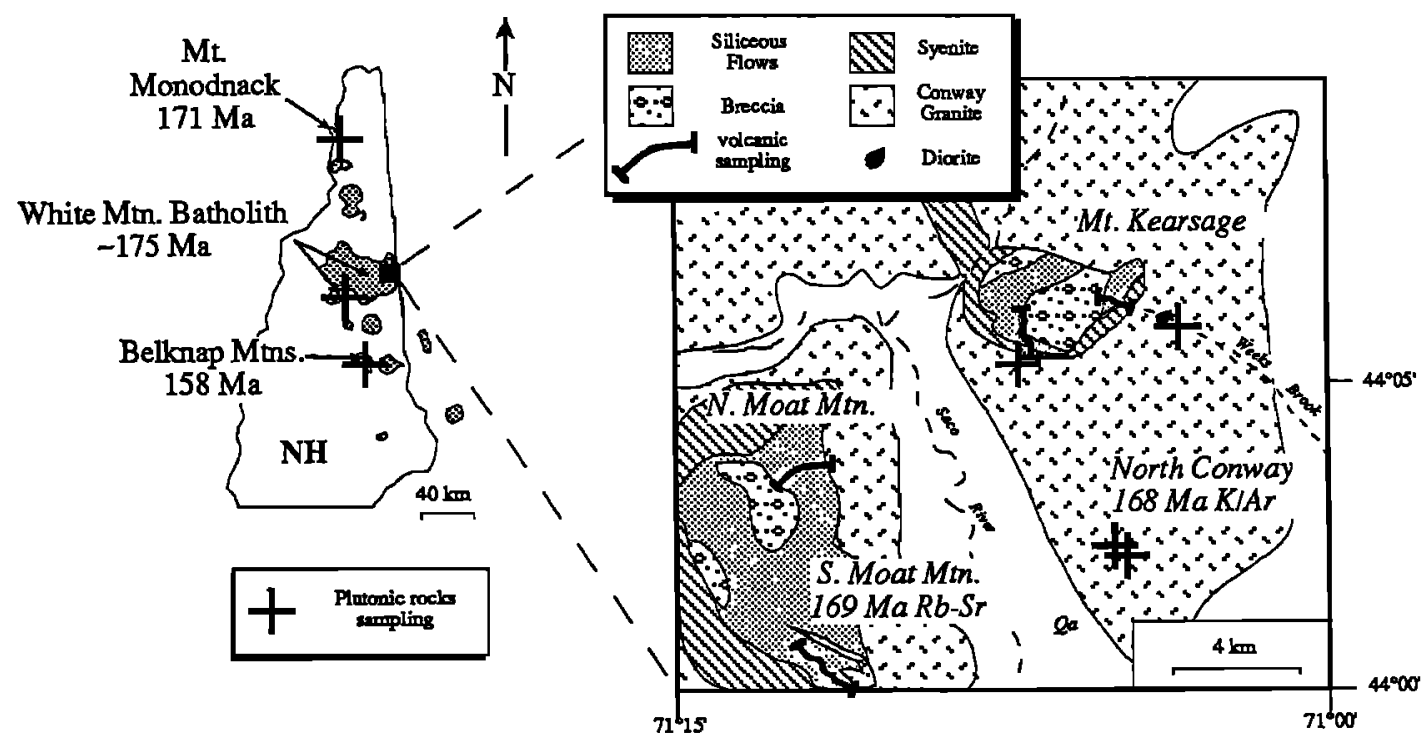

Fig. 2. A sketch map of the White Mountains Magma Series, New England showing sampling localities. The inset is a portion of the North Conway quadrangle [after Billings, 1928]. Our four Jurassic pluton sampling localities are (from north to south) Mount Monadnock, North Conway (see inset), Mad River, and the Belknap Mountains. The Moat volcanics sampling areas as shown in the inset are Mount Kearsage, North Moat Mountain, and South Moat Mountain. At Kearsage the beds strike east-west and dip nearly vertical. Bedding surfaces along North and South Moat mountains dip moderately easterly toward the center of the structure and strikes generally follow the trend of the syenite partial ring dike, although this is difficult to observe at North Moat Mountain.

diorite plug may be all that remains of a more mafic form of the magma chamber that later fractionated Conway granite magmas [Billings, 1928]. About $27 \mathrm{~km}$ to the southwest of this locality we have sampled, at one site, Conway granite of the Mad River "satellite" stock of the White Mountains batholith (Figure 2). The granite here has yielded a $\mathrm{Rb}-\mathrm{Sr}$ whole rock age of $194 \pm 4 \mathrm{Ma}$ [Foland et al., 1971]. K-Ar biotite ages available from Mad River are 180 and $181 \pm 4 \mathrm{Ma}$ [Foland and Faul, 1977] and like the White Mountains batholith, apatite fission-track ages are Cretaceous (102 $\pm 16 \mathrm{Ma}$ [Doherty : ind Lyons, 1980]).

At Mount Monadnock in northeastern Vermont (Figure 2), Opdyke and Wensink [1966] sampled two sites: one site a lamprophyre, the other an essexite body. The essexite specimens were retrieved from our sample archive for further study. A K-Ar biotite age of $171 \pm 4 \mathrm{Ma}$ is available from the Mount Monadnock Conway granite [Foland and Faul, 1977]. Zircon and apatite fission track ages of $165 \pm 12$ and $114 \pm 8$ $\mathrm{Ma}$, respectively, are available from syenite exposed here [Doherty and Lyons, 1980].

In the Belknap Mountains of south central New Hampshire (Figure 2), we have sampled six'sites of quartz syenite and quartz diorite which form a partial ring dike; a stock of Conway granite surrounded by the Belknap ring dike has also been sampled at one site. Opdyke and Wensink [1966] sampled two sites of monzonite along the southem perimeter of the Belknap complex. Syenite from the Belknap Mountains has been radiometrically dated as $158 \pm 3$ and $164 \pm 5 \mathrm{Ma}(\mathrm{Rb}-\mathrm{Sr}$ biotite [Foland and Faul, 1977]). The available $\mathrm{K}-\mathrm{Ar}$ ages are very similar (about $158 \mathrm{Ma}$ [Foland et al., 1971; Foland and Faul, 1977]) and apatite fission track ages are $87 \pm 7 \mathrm{Ma}$ (Zimmerman et al. [1975], recalculated by Doherty and Lyons [1980]).
A second group of Jurassic rocks were sampled in this study, these being the effusive rocks known as the Moat volcanics. These pyroclastic quartz trachyte and comendite flows, ash flow tuffs and breccias were first named and mapped by Billings [1928]. We sampled the two known exposures on the eastern side of the Jurassic White Mountains batholith : one on the Moat Range (North and South Moat mountains), the other to the east on Mount Kearsage (see inset, Figure 2). Collectively, the Moat volcanics represent an effusive phase of the White Mountains Magma Series. An intrusive contact with younger, radiometrically dated Conway granite ( $168 \pm 3 \mathrm{Ma} \mathrm{K}$-Ar biotite age [Foland et al., 1971]) provides a minimum age for the subsided volcanics. A Rb-Sr whole rock age of $175 \mathrm{Ma}$ has been reported for the Moat volcanics on South Moat Mountain [Eby and Creasy, 1983] and further work gives a revised $\mathrm{Rb}-\mathrm{Sr}$ age of $169 \mathrm{Ma}$ with a standard error of only a few million years (J. Creasy, personal communication, 1989).

It has been suggested that most of the original Moat volcanic material has since been eroded. Minimum original thicknesses have been estimated at $3100 \mathrm{~m}$ or more [Billings, 1928, 1956] and what we see today is that which had subsided into granitic magma chambers. Recently, detailed mapping of the rocks on North and South Moat mountains have confirmed an intracaldera setting [Fitzgerald and Creasy, 1988]. Coarsegrained Pequawket breccia is found near the quartz syenite ring dike that borders the western side of the North and South Moat mountains exposure. The breccia and associated bedded tuffs, thickest near this ring dike, thin and dip radially inward $\left(25^{\circ}\right.$ $40^{\circ}$ ) with strikes that appear to parallel the dike, although the exact structure at North Moat is more difficult to ascertain. The Moat volcanics at Mount Kearsage may represent an isolated roof pendant that fell into a magma chamber due to extensive magma stoping [Billings, 1928]; flows and breccias here strike 
nearly east-west and dip about $85^{\circ}$ to the south.

We have sampled quartz trachyte, ash flow tuff, and breccia of the Jurassic Moat volcanics at 24 sites, 10 on North Moat Mountain, six on South Moat Mountain, and eight on Mount Kearsage (inset, Figure 2). The sampling sites, taken in stream cuts, were positioned over the field area in such a way as to achieve representative geographic and stratigraphic coverage. Typically, five core samples were drilled at each site and were oriented with a Brunton compass; sun compass checks showed negligible deflections.

\section{PALEOMAGNETTC ResUlts}

Our experimental plan was originally designed with the intention of expanding the Opdyke and Wensink [1966] study by comprehensive sampling of Jurassic plutons in New England. We soon realized that progressive alternating field (AF) and thermal demagnetizations on the initial collection of plutonic rocks simply confirmed the existence of a single component, normal polarity magnetization. However, a pilot study on the Moat volcanics revealed more complex, multicomponent magnetizations and we thus concentrated on this more promising rock unit. All magnetization components identified from progressive demagnetization were analyzed with principal component analysis [Kirschvink, 1980] and mean directions calculated according to standard Fisher [1953] statistics.

\section{Jurassic Plutonic Rocks}

Even after extensive AF and thermal demagnetization, the paleomagnetic directions from the Jurassic plutonic lithologies are similar to those reported by Opdyke and Wensink [1966]. The demagnetization trajectories are relatively straightforward, with univectorial decay to the origin of a normal polarity component generally along the direction of the dipole field in New England. A direct demonstration of this are data from the essexites of Mount Monadnock studied as site 11 of Opdyke and Wensink [1966]. We were able to retrieve the samples and orientation information from this site and performed further AF cleaning, followed by thermal demagnetization on the original samples. These essexites are strongly magnetized, with average natural remanent magnetization (NRM) intensities as reported by Opdyke and Wensink of $5.7 \mathrm{~A} / \mathrm{m}$. A single, high coercivity (>90 m'T) and high unblocking temperature (up to $580^{\circ} \mathrm{C}$ ) magnetization, exclusively of normal polarity is present (Figure $3 a$ ). These new demagnetization profiles give directions (declination = $356.8^{\circ}$, inclination $=+61.8^{\circ} ; n=6$ samples) very similar to the magnetizations reported for the site by Opdyke and Wensink [1966] following AF demagnetization to only $15 \mathrm{mT}$ (declination $=1^{\circ}$, inclination $=+65.5^{\circ} ; n=8$ samples). A mean direction for Mount Monadnock was calculated using two site means: one from site 12 of Opdyke and Wensink (original [a] Mount Monadnock (essexite)

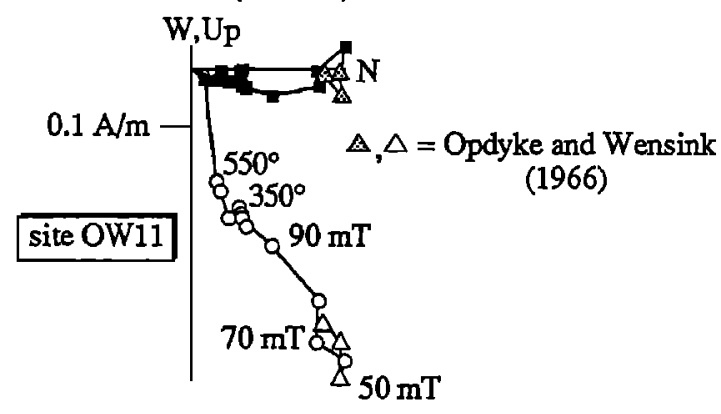

[c] White Mtr. Batholith (Conway granite at Mad River)

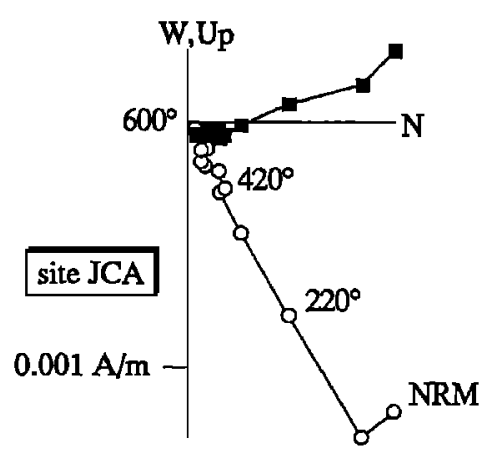

[d] White Mtn. Batholith

(Conway granite)

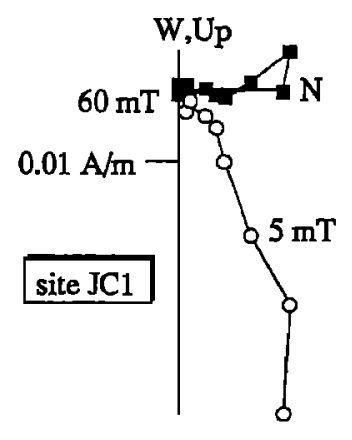

[b] White Mm. Batholith (Albany quartz syenite at Mt. Kearsage)

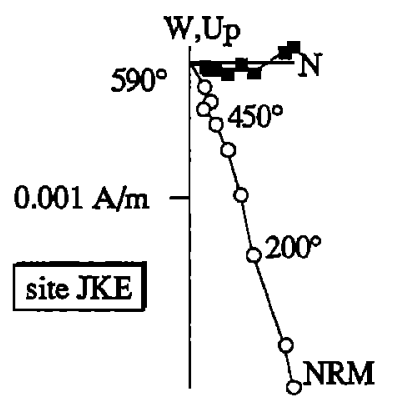

[e] Belknap Mountains (Conway granite)

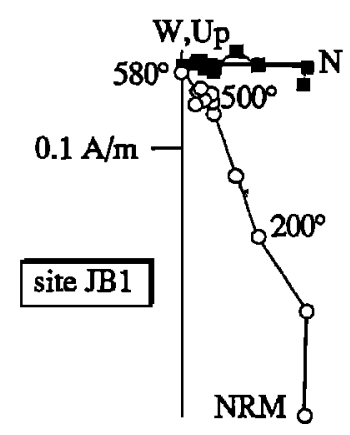

Fig. 3. Demagnetograms representing progressive altemating field (AF) and themal demagnetization of the "P" component from Jurassic plutonic rocks of the White Mountains Series. Open (solid) symbols illustrate vertical (horizontal) orthogonal projection of vector end-points. Temperatures are given in degrees Celsius: altemating fields in millitesla (mT). (a) Essexite from Mount Monadnock, where the triangles represent the measurements from Opdyke and Wensink [1966], circles measurements made subsequently by us; $(b)$ thermal demagnetization of Albany quartz syenite from the White Mountains batholith (Mt. Kearsage); (c) thermal demagnetization of Conway Granite from the White Mountains batholith (Mad River stock); (d) AF demagnetization of Conway Granite from the White Mountains batholith; (e) thermal demagnetization of Conway Granite from the Belknap Mountains. 
orientation data for this site was lost; hence we did no further work on the samples) consisting of 11 lamprophyre samples demagnetized to $15 \mathrm{mT}$ (declination $=5^{\circ}$, inclination $=+63^{\circ}$; $\mathrm{NRM}$ intensities $=0.65 \mathrm{~A} / \mathrm{m}$ ), the other a site mean calculated using results from our further $\mathrm{AF}$ and thermal demagnetizations on samples of Opdyke and Wensink's site 11 . This Mount Monadnock mean has declination of $0.8^{\circ}$ and inclination of $62.5^{\circ}$ (Table 1 and Figure 4).

Similarly, AF and thermal demagnetization experiments on plutonic rocks from the White Mountains batholith yielded a univectorial, normal polarity magnetization. Average NRM intensities of samples from the batholith are approximately 35 $\mathrm{mA} / \mathrm{m}$, while the Mad River stock NRM intensities are 1.5 $\mathrm{mA} / \mathrm{m}$. The magnetization in the Albany quartz syenite and diorite (near Mount Kearsage) and Conway granite (near North Conway and along Mad River) has unblocking temperature up to about $590^{\circ} \mathrm{C}$, appropriate for magnetite (Figures $3 b$ and $3 c$ ) and, with the exception of samples from two sites of Conway Granite at North Conway, is also of moderate to high coercivity. NRM intensities of granite at North Conway are nearly halved by applied fields of just $30 \mathrm{mT}$, yet continue to

TABLE 1. Paleomagnetic Data From Jurassic Plutons of the White Mountains Magma Series, New England

\begin{tabular}{ccccccccc}
\hline Locality & $N$ & $R$ & $k$ & $\alpha 95$ & \multicolumn{2}{c}{ In Situ } & $I$ \\
\hline $\begin{array}{c}\text { Mount Monadnock } \\
171 \mathrm{Ma}\end{array}$ & 2 & 1.998 & 829 & - & 0.8 & 62.5 \\
$\begin{array}{c}\text { White Mountain Batholith } \\
\text { 175 Ma }\end{array}$ & 5 & 4.987 & 302 & 4.4 & 359.0 & 64.3 \\
$\begin{array}{c}\text { Belknap Mountains } \\
\text { 160 Ma }\end{array}$ & 5 & 4.974 & 160 & 6.1 & 2.9 & 57.5 \\
& & & & & &
\end{tabular}

$N$, the number of site mean directions; $R$, resultant vector length of total number of site mean vectors; $k$, Fisher dispersion parameter; $\alpha 95$, radius of $95 \%$ confidence about the mean; In situ $D, I$, the declination and inclination of the site mean magnetization. demagnetize along origin-bound trajectories until about 50-60 $\mathrm{mT}$, at which point the magnetizations become very weak and difficult to measure (Figure $3 d$ ). The stable components from five sites of the White Mountains batholith give a well-defined mean magnetization direction of declination $=359.0^{\circ}$, inclination $=64.3^{\circ}$, with an $\alpha 95$ of $4.4^{\circ}$ (see Table 1).

At the Belknap Mountains in south central New Hampshire, a stable normal polarity magnetization was found in three of seven sites (Figure $3 e$ ). NRM intensities among these three stable sites ranged from $45 \mathrm{~mA} / \mathrm{m}$ (sites $\mathrm{JB} 2$ and 3 , diorite) to about $350 \mathrm{~mA} / \mathrm{m}$ (site JB1, Conway Granite). Samples from four quartz syenite sites (NRM intensities: $55-120 \mathrm{~mA} / \mathrm{m}$ ) yielded unstable magnetizations and were excluded from further study. Our Belknap component mean $(N=3$ sites, declination $=3.8^{\circ}$, inclination $=54.4^{\circ}, \alpha 95=9.3^{\circ}$ ) is similar to the directions of the original Belknap site mean magnetizations reported by Opdyke and Wensink (site 4: declination $=0^{\circ}$, inclination $=65^{\circ} ;$ site 5 : declination $=2^{\circ}$, inclination $=59^{\circ}$ ).

In summary, the three Jurassic plutons studied (Mount Monadnock, $171 \mathrm{Ma}$; White Mountains batholith, $175 \mathrm{Ma}$; Belknap Mountains, $160 \mathrm{Ma}$ ) carry a moderate to high coercivity, high unblocking temperature magnetization referred to as the $\mathrm{P}$ component, with a mean declination of $1.5^{\circ}$ and inclination of $60.4^{\circ}\left(\alpha_{95}=8.3^{\circ}, N=3\right.$ plutonic complexes, Table 1). This direction confirms the result of Opdyke and Wensink [1966] with the added enhancement of thermal demagnetization studies; it deviates from the ambient geomagnetic field but is not significantly different from the average dipole field direction over the sampling localities (inclination $=63^{\circ}$ ).

\section{Moat Volcanics}

Thermal and AF demagnetization experiments have enabled us to identify a stable dual polarity component of magnetization (referred to as the $\mathrm{C}$ component) at the three Moat volcanics sampling localities: North and South Moat Mountain (the Moat Range) and Mount Kearsage. Coercivities of the $C$ component generally exceed $100 \mathrm{mT}$ (Figure $5 a$ ) and maximum unblocking temperatures typically range up to about $600^{\circ} \mathrm{C}$ (Figures $5 b$ and 5c) but at South Moat Mountain site JMM and Mount Kearsage

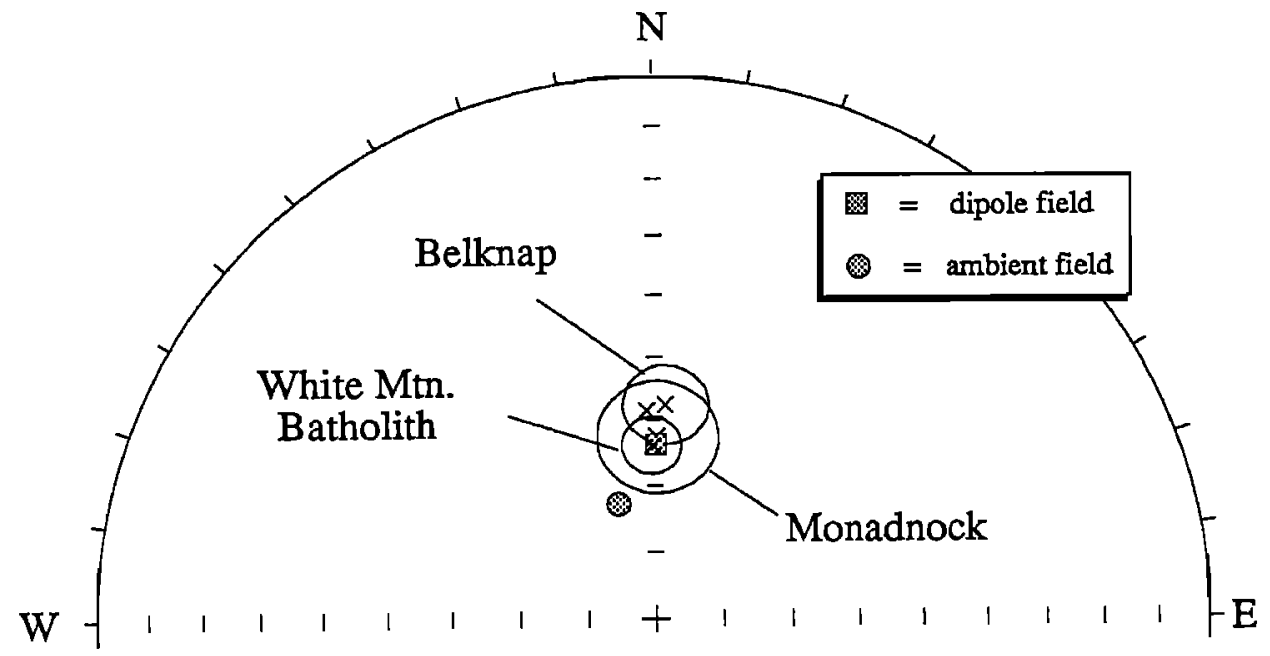

Fig. 4. Lower hemisphere, stereographic projection of mean directions along with cones of $95 \%$ confidence from Jurassic plutons studied here. Shaded square represents the geocentric axial dipole field direction; shaded circle represents the direction of the present-day field in central New Hampshire. 
[a] S. Moat Mtn: A, Cr components.

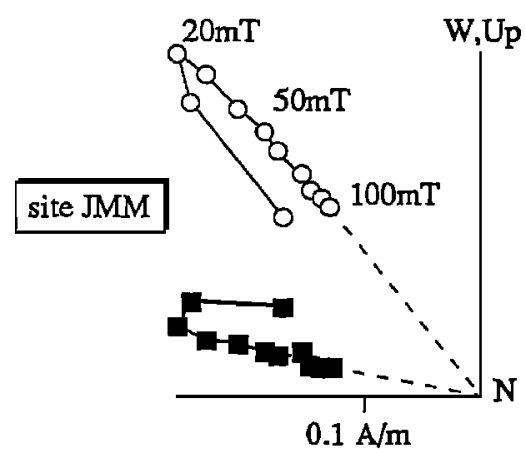

[c] Mt. Kearsage: Cn component.

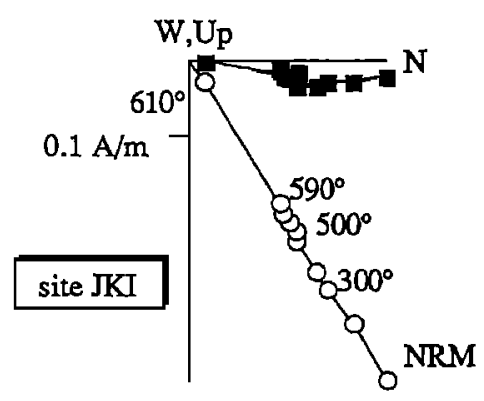

[e] N. Moat Mtn.: B component.

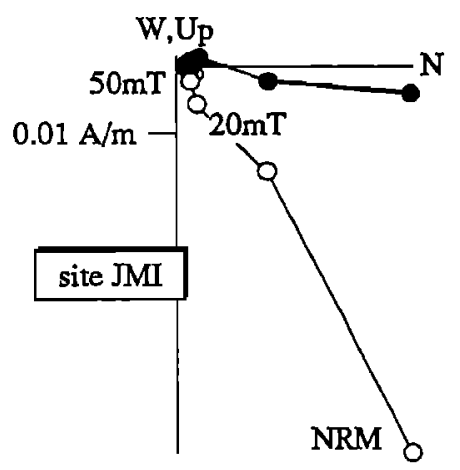

[b] S. Moat Mtn.: A, Cr components.

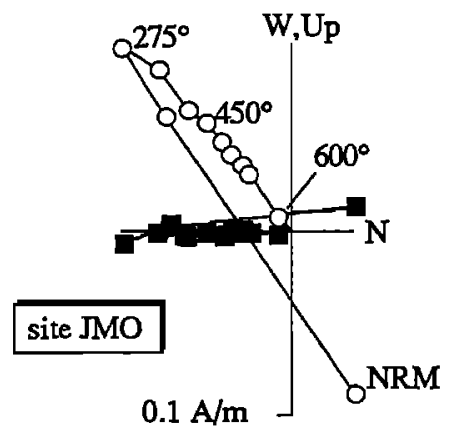

[d] Mt. Kearsage: Cr component.

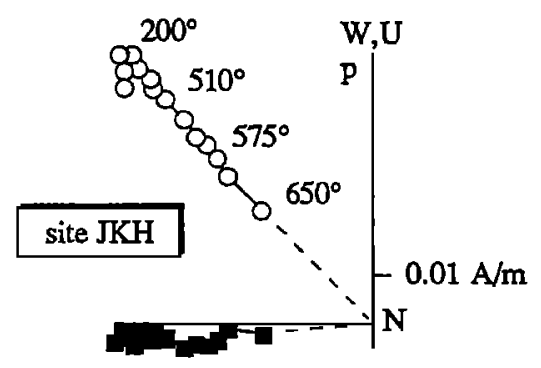

[f] N. Moat Mtn.: B component.

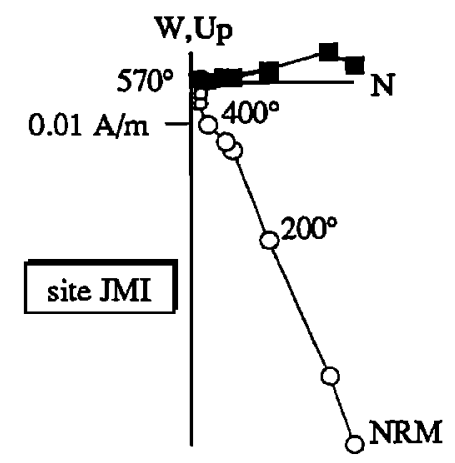

Fig. 5. Demagnetograms representing progressive alternating field and themal demagnetization of the Jurassic Moat volcanics. No structural corrections have been applied and symbols are those used in Figure 3. Examples shown are (a) altemating field and $(b)$ thermal demagnetization of quartz trachyte from South Moat Mountain illustrating the reversed polarity " $\mathrm{Cr}$ " component and normal polarity, low stability "A" component; thermal demagnetization of the (c) $\mathrm{Cn}$ component and (d) $\mathrm{Cr}_{\mathrm{r}}$ component from Mount Kearsage quartz trachyte; (e) alternating field and $(f)$ thermal demagnetization of ash flow tuff from North Moat Mountain showing the lower stability "B" magnetization.

site $\mathrm{JKH}$, extend to above $650^{\circ} \mathrm{C}$ (Figure $5 d$ ). In many samples a substantial fraction of the $\mathrm{C}$ component is only removed over the final $20^{\circ}$ of thermal treatment.

Of particular interest is the reversed polarity $\mathrm{Cr}$ component, which is found mainly in the Moat Range (sites JMA and JMB in ash flow tuffs at North Moat Mountain and sites JMK through $P$ in quartz trachytes at South Moat Mountain) but also in the older of two flows at Mount Kearsage (site JKH, Figure $5 d$ ) where essentially the antipodal but also highly stable normal polarity component ( $\mathrm{Cn}$ component, Figure $5 c$ ) is otherwise found exclusively. The high coercivity, high unblocking temperature, and reversed polarity $\mathrm{Cr}$ component yields a mean direction with declination $=184.3^{\circ}$ and inclination $=-52.7^{\circ}\left(\alpha 95=7.4^{\circ}\right.$ for nine sites $)$. The high stability, normal polarity $\mathrm{Cn}$ component has been resolved at seven sites from Mount Kearsage (declination $=2.1^{\circ}$; inclination $=59.1^{\circ} ; \alpha_{95}=7.0^{\circ}$ ). Note that we divided site $\mathrm{JKH}$ (at Mount Kearsage) into two individual sites post facto, 
having discovered the $\mathrm{Cn}$ component (three samples) and the Cr component (also three samples) in the older and younger flows, respectively, at this site. Due to lack of linear demagnetization trajectories, site JKB (of Mount Kearsage) and sites JMF and $G$ (North Moat) were eliminated from further study. Thus the dual polarity $\mathrm{C}$ component is carried by 16 sites in the Moat Range and Mount Kearsage and the mean of these data (averaged by site and inverting to common polarity) has declination $183.4^{\circ}$ and inclination $-55.5^{\circ}\left(\alpha 95=5.0^{\circ}\right)$.

Less stable magnetizations are also observed in the Moat volcanics. Most obviously present at seven of the eight Moat Range sites that carry the $\mathrm{Cr}$ component is a normal polarity overprint of variable magnitude but which is readily removed by $20 \mathrm{mT}$ or $300^{\circ} \mathrm{C}$ (Figures $5 a$ and $5 b$ ). On the basis of its low stability and mean direction (declination $=350.6^{\circ}$, inclination $=65.7^{\circ}, \alpha 95=6.6^{\circ}$ for $N=7$ sites), which conforms to that of the present-day field (declination $=344^{\circ}$, inclination $=71^{\circ}$ ) at the sampling locality, we conclude that this (A) component most likely represents a recent viscous magnetization.

More difficult to interpret is a low to moderate stability, normal polarity component found in six sites of ash flow tuffs from North Moat Mountain (JMC,D,E,H,I, and J). This (B) component is effectively removed by about $50 \mathrm{mT}$ (Figure $5 e$ ), and, while unblocking temperatures may extend to $570^{\circ} \mathrm{C}$, only a small fraction of the NRM remains after $300^{\circ} \mathrm{C}$ (Figure $5 f$ ). The mean direction of the $\mathrm{B}$ component (declination $=358.1$, inclination $=61.6^{\circ}, \alpha_{95}=10.7^{\circ}, N=6$ sites) is similar to that of the A component overprint. In addition to lower magnetic stabilities, the B component tuffs are also distinguished by NRM intensities and initial susceptibilities that are lower by at least an order of magnitude than the tuffs and quartz trachytes from the Moat Range that carry the high stability $C$ component. We thus suppose that the B component tuffs represent cases in which the original $\mathrm{C}$ component is nearly absent, effectively dominated by a more recent overprint.

The thermal and AF demagnetization experiments suggest that the Moat volcanics NRM is carried mainly by magnetite. This conclusion is supported by isothermal remanent magnetization (IRM) acquisition curves which show that magnetic saturation is achieved with applied fields of $400 \mathrm{mT}$ or less (Figure 6). However, given the high unblocking temperature and high coercivity demagnetization profiles of samples from sites JMM (South Moat Mountain) and JKH (Mount Kearsage),

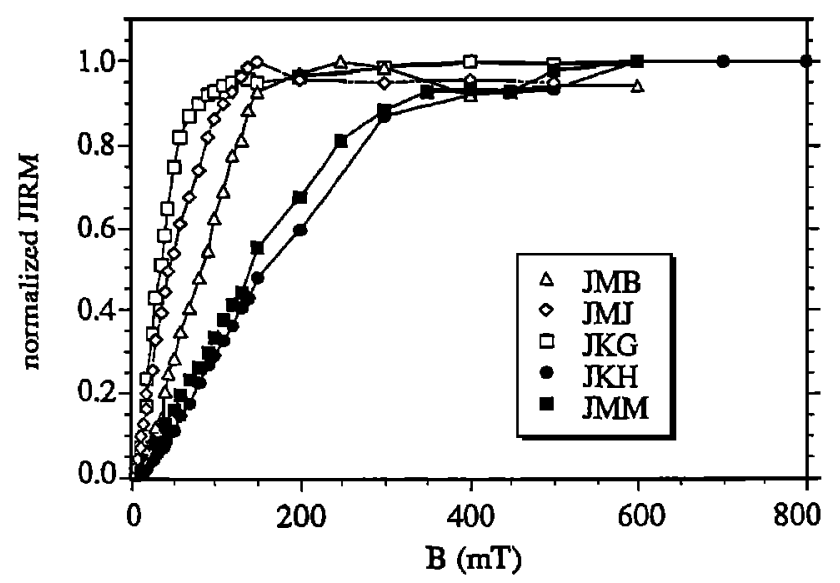

Fig. 6. Normalized isothermal remanent magnetization (IRM) acquisition curves of representative samples from the Moat volcanics. hematite must also make some contribution to the NRM of these sites. The relatively inefficient acquisition of IRM in these samples (Figure 6) presumably is the manifestation of this hematite contribution. Polished and thin section observations confirm the presence of hematite and magnetite in the ground mass of samples from sites JMM and JKH. Fine-grained magnetite dominates the ground mass of samples from the other Moat volcanics sites where demagnetization and IRM acquisition data suggest a negligible contribution of hematite. In all observed thin sections, phenocrysts of orthoclase feldspar show severe alteration with mainly clay minerals and minor magnetite occuring along crystallographic cleavage planes.

Variety in bedding attitude of the Moat volcanics allows application of a "tilt" test. Stereographic plots of the $16 \mathrm{C}$ component site means clearly show an increase in dispersion following the correction for tilt (Figures $7 a$ and $7 b$ ). This negative tilt test is significant at the $99 \%$ confidence level, and it indicates that the $\mathrm{C}$ component represents a secondary magnetization and should be considered in the in situ reference frame. Although the $A$ and $B$ components do not give a statistically decisive tilt test because of the more limited range in bedding attitudes of the relevant sites, these low stability components also appear to be posttilting as might be expected (Table 2).

Although the tilt test indicates remagnetization, acquisition in the recent field cannot account for the reversed polarity $\mathrm{Cr}$ component whose direction is in any case significantly shallower than the dipole axis (inclination $=+63^{\circ}$ or $-63^{\circ}$ ). Normal polarity component $\mathrm{C} n$, however, has a mean direction that is statistically indistinguishable from the dipole field axis, even though this component has high stability, similar to that of component $\mathrm{Cr}$, with respect to which it is statistically antiparallel ( $99 \%$ confidence level by method of McFadden and Lowes [1981]). It is therefore possible that component $\mathrm{Cn}$ is approximately coeval with ancient component $\mathrm{Cr}$ : The somewhat shallower mean direction of $\mathbf{C r}$ (inclination $=-52.7^{\circ}$ ) compared to $\mathrm{Cn}$ (inclination $=59.1^{\circ}$ ) could be accounted for by some unremoved contamination in either or both original component(s) by a steeper component (say, the present-day-field component $A$, inclination $=65.7^{\circ}$; Figure 7c). A combined mean of the nine reversed and seven normal sites would tend to average out the effect of such contamination yielding an overall mean (declination $=3.4^{\circ}$, inclination $=55.5 ; \alpha 95=5.0^{\circ}$ ) that is statistically distinguishable from the time-averaged dipole field. However, given the uncertainty in how the alleged contamination is distributed among reversed and normal sites, and considering also that the Cn component conforms in polarity and direction to the dipole field, the reversed polarity $\mathrm{Cr}$ component may provide the more conservative estimate of the ancient field direction. Recent field contamination would tend to shallow $\mathrm{Cr}$, and thus if some unremoved contamination indeed exists, we at least know that the true $\mathrm{Cr}$ direction is no shallower than $-52.7^{\circ}$. The $\mathrm{Cr}$ component therefore places a lower limit on the inclination of the Moat volcanics high unblocking temperature, high coercivity, and dual polarity $\mathrm{C}$ magnetization.

\section{POLE POSTITONS AND INTERPRETATION}

The normal polarity components of Jurassic White Mountains igneous rocks identified in this study, which on the basis of high magnetic stability might be expected to record ancient magnetic field directions, nevertheless give pole 


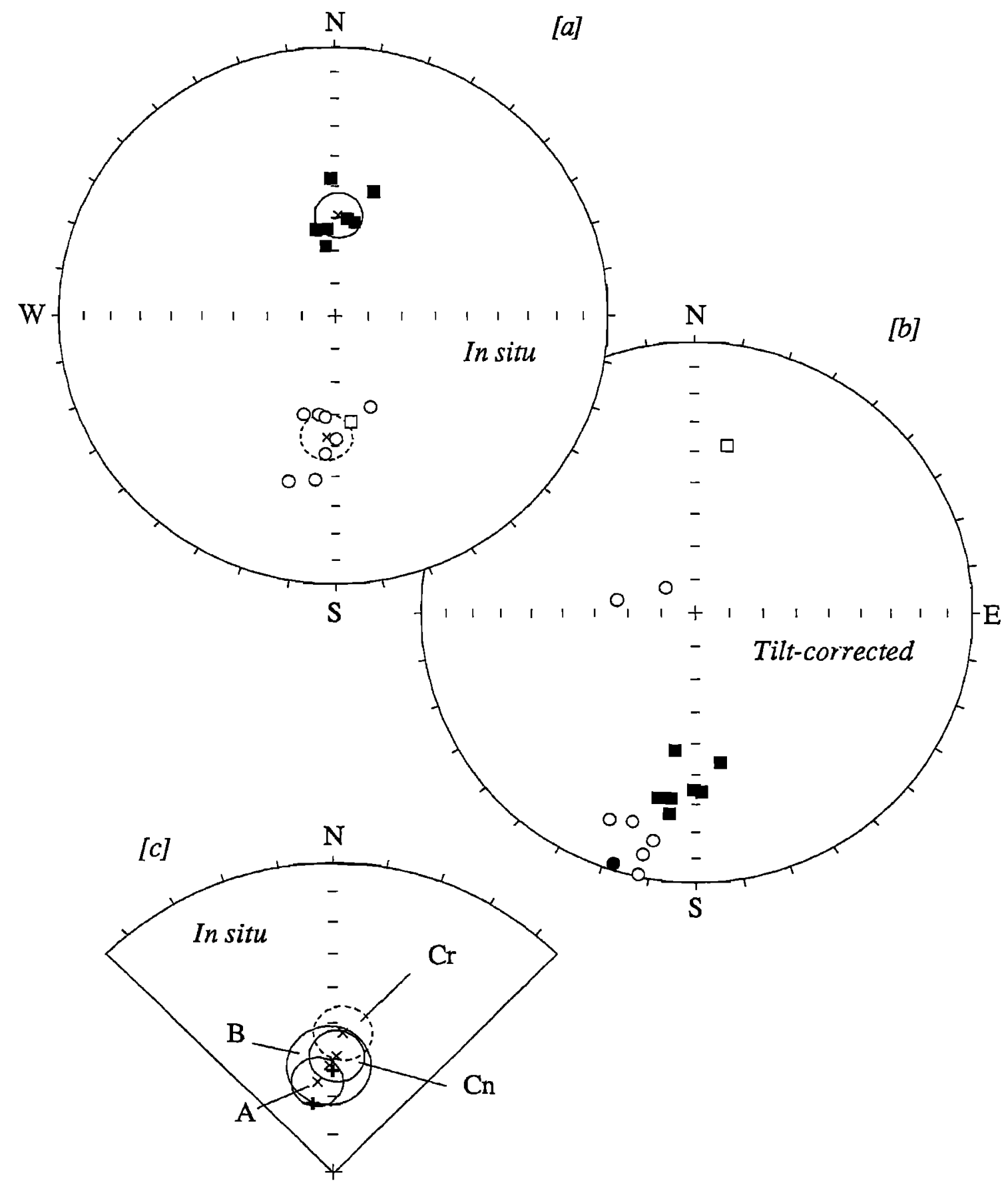

Fig. 7. Stereographic projections of site mean directions of magnetization components isolated from the Moat volcanics. (a) In in situ coordinates, the normal polarity mean directions (solid symbols, lower hemisphere) represent the $\mathrm{Cn}$ component: the reversed polarity directions (open symbols, upper hemisphere) represent the reversed polarity Cr component (circles, North and South Moat Mountain; squares, Mount Kearsage). (b) When the volcanic rocks are corrected for tilt, dispersion greatly increases and the data fail the tilt test at $99 \%$ confidence. (c) The in situ $\mathrm{A}, \mathrm{B}, \mathrm{Cr}$, and $\mathrm{Cn}$ component mean directions and $95 \%$ cones of confidence are shown in magnified view. The antipode of the Cr component mean is shown for easy comparison with $\mathrm{A}, \mathrm{B}$, and $\mathrm{Cn}$.

positions which are statistically coincident with geographic north: the plutonic rocks $\mathrm{P}$ component pole at $88.4^{\circ} \mathrm{N}, 82.1^{\circ} \mathrm{E}$ $\left(A 95=6.1^{\circ}\right)$ and the Moat volcanics $C n$ component pole at $85.5^{\circ} \mathrm{N}, 87.4^{\circ} \mathrm{E}\left(d p=7.8^{\circ}, d m=10.5^{\circ}\right.$; Table 3$)$. The volcanic A $\left(82.4^{\circ} \mathrm{N}, 232.9^{\circ} \mathrm{E}, d p=8.7^{\circ}, d m=10.7^{\circ}\right)$ and $\mathrm{B}\left(88.1^{\circ} \mathrm{N}\right.$, $154.6^{\circ} \mathrm{E}, d p=12.8^{\circ}, d m=16.5^{\circ}$ ) component poles also are statistically coincident with the dipole axis but this is not unexpected given the low stability of these components.
As discussed earlier, a volumetrically significant magmatic event took place in the White Mountains region during the Cretaceous (mean age: $115 \pm 7 \mathrm{Ma}$ [Foland and Faul, 1977]). The heat and/or hydrothermal fluids associated with this event could have disturbed Jurassic magnetizations in the region. However, none of the pole positions of this study, particularly the $\mathrm{P}$ and $\mathrm{Cn}$ component poles, conform with the Cretaceous paleomagnetic field for North America. Nevertheless, the 
TABLE 2. Summary of Paleornagnetic Mean Data From the Moat Volcanics

\begin{tabular}{|c|c|c|c|c|c|c|c|c|c|c|c|}
\hline \multirow[b]{2}{*}{ Component } & \multirow[b]{2}{*}{$M n]$} & \multicolumn{5}{|c|}{ In Sim } & \multicolumn{5}{|c|}{ Tilt Corrected } \\
\hline & & $R$ & $k$ & $\alpha 95$ & $D$ & $I$ & $\underline{R}$ & $k$ & $\alpha 05$ & $D$ & $I$ \\
\hline $\begin{array}{l}\text { A component } \\
\text { North and South Moat Mountains }\end{array}$ & 7 & 6.929 & 85 & 6.6 & 350.6 & 65.7 & 5.824 & 5 & 29.6 & 19.5 & 46.0 \\
\hline $\begin{array}{l}\text { B component } \\
\text { North Moat Mountain }\end{array}$ & 6 & 5.875 & 40 & 10.7 & 358.1 & 61.6 & 5.875 & 40 & 10.7 & 108.9 & 71.1 \\
\hline $\begin{array}{c}\text { Cr component } \\
\text { North Moat Mountain } \\
\text { South Moat Mountain } \\
\text { Mount Kearsage } \\
\text { Mean Cr }\end{array}$ & $\begin{array}{c}2 \\
6 \\
1[3] \\
9\end{array}$ & $\begin{array}{l}1.982 \\
5.914 \\
2.959 \\
8.837\end{array}$ & $\begin{array}{l}57 \\
58 \\
50 \\
49\end{array}$ & $\begin{array}{r}- \\
8.8 \\
17.7 \\
7.4\end{array}$ & $\begin{array}{l}174.3 \\
188.5 \\
171.6 \\
184.3\end{array}$ & $\begin{array}{l}-60.8 \\
-48.9 \\
-57.4 \\
-52.7\end{array}$ & $\begin{array}{l}1.982 \\
5.914 \\
2.959 \\
7.000\end{array}$ & $\begin{array}{r}57 \\
58 \\
50 \\
4\end{array}$ & $\begin{array}{r}\overline{8.8} \\
17.7 \\
29.5\end{array}$ & $\begin{array}{r}289.6 \\
195.1 \\
10.9 \\
199.6\end{array}$ & $\begin{array}{l}-73.1 \\
-10.3 \\
-36.8 \\
-19.7\end{array}$ \\
\hline $\begin{array}{l}\text { Cn component } \\
\text { Moumt Kearsage }\end{array}$ & 7 & 6.920 & 75 & 7.0 & 2.1 & 59.1 & 6.920 & 75 & 7.0 & 183.9 & 35.9 \\
\hline Mean C component & 16 & 15.732 & 56 & 5.0 & 183.4 & -55.5 & 13.457 & 6 & 16.6 & 187.0 & 24.0 \\
\hline
\end{tabular}

$N[n]$, the number of site mean [sample] directions; $R$, resultant vector length of total number of site mean vectors; $k$, Fisher dispersion parameter, $\alpha 95$, radius of $95 \%$ confidence about the mean; In situ $D, I$, the declination and inclination of the site mean magnetization prior to tilt correction; Tilt corrected $D$ and $I$, the declination and inclination of the site mean magnetization following the tilt correction.

combination of directions and normal polarity of the $\mathrm{P}$ and $\mathrm{Cn}$ components makes it difficult to allay suspicions that the high stability paleomagnetic signal has somehow been contaminated by recent magnetizations.

On the basis of its reversed polarity alone, the Moat volcanics $\mathrm{Cr}$ component cannot represent a recent remagnetization even though a secondary origin is indicated by a negative tilt test. Moreover, although the $\mathrm{Cr}$ component (north) pole falls at high latitude $\left(78.7^{\circ} \mathrm{N}, 90.3^{\circ} \mathrm{E}, d p=7.1^{\circ}\right.$, $\left.d m=10.2^{\circ}\right)$, it is statistically distinct from the geocentric axial dipole field and in fact does not correspond to what might be currently regarded as reliable Jurassic or Cretaceous reference poles for North -America. The pole position might indicate remagnetization sometime in the late Tertiary (Figure 8) but published thermochronometrical data argue against a Tertiary

TABLE 3. Paleomagnetic Pole Position Data From Jurassic Plutons and Moat Volcanics of the White Mountains Magma Series, New Hampshire

\begin{tabular}{cccccc}
\hline & & \multicolumn{2}{c}{ Pole } & & \\
\cline { 3 - 5 } Unit & $N$ & Latitude & Longitude & $d p$ & $d n$ \\
\hline Plutons $169 \pm 8 \mathrm{Ma}$ & & & & & \\
P component & 3 & 88.4 & 082.1 & $6.1 *$ & \\
& & & & & \\
Moat volcanics $166 \mathrm{Ma}$ & & & & & \\
Cr component & 9 & 78.7 & 090.3 & 7.1 & 10.2 \\
Cn component & 7 & 85.5 & 087.4 & 7.8 & 10.5 \\
C component & 16 & 81.6 & 089.7 & 5.1 & 7.1 \\
B component & 6 & 88.1 & 154.6 & 12.8 & 16.5
\end{tabular}

$N$, the number of sites for Moat volcanics and plutons for $P$ component; Pole latitude and longitude in situ coordinates; $d p$ and $d m$, 95\% confidence ellipse semi-axes parallel and perpendicular (respectively) to the site-to-pole meridian.

*A95, radius of $95 \%$ confidence about the mean pole. thermal event. As summarized above, the similarity in the $\mathrm{Rb}$ Sr whole rock age on the Moat volcanics (169 Ma) compared to the $\mathrm{K}$-Ar biotite age (168 Ma) and zircon fission track age (163 $\mathrm{Ma}$ ) on the intruding Conway granite, indicates rapid initial cooling. This was likely followed by gradual unroofing given the apatite fission track age ( $94 \mathrm{Ma}$ ) but in any case, we are not aware of any thermochronometrical data from the White Mountains batholith that would suggest a post-Cretaceous thermal event. An alleged Tertiary remagnetization event would also have had to be rather selective, somehow affecting only the Jurassic rocks because Triassic and Cretaceous igneous rocks of the White Mountains Series do not show evidence of a Tertiary resetting [Opdyke and Wensink, 1966; Van Fossen and Kent, 1988; Wu and Van der Voo, 1988].

We therefore suggest that the $\mathrm{Cr}$ component was acquired as a thermo(chemical) remagnetization, perhaps in conjunction with growth of iron oxides through devitrification of volcanic glass, shortly following collapse and tilting of the Moat volcanics within the White Mountains caldera(s) as described above. Demagnetization analyses of NRM and bulk rock magnetism strongly suggest that this remagnetization signal is carried predominantly by magnetite with some contribution from hematite at certain localities. Remagnetization age is no older than $169 \mathrm{Ma}$ (Rb-Sr age on the Moat volcanics) and is unlikely to be younger than $163 \mathrm{Ma}$ (zircon fission track cooling age of the intruding granite); hence we assume a nominal age of $166 \mathrm{Ma}$ which is late Middle Jurassic (Callovian) according to the Decade of North American Geology (DNAG) time scale [Palmer, 1983]. Acquisition of remanence must have spanned at least one geomagnetic polarity reversal if the normal polarity $\mathrm{Cn}$ component is regarded as of similar ancient origin. In this regard, Steiner et al. [1987] suggest that the Middle Jurassic is an interval of frequent reversals, but there should be adequate time represented to average secular variation. Finally, any regional tilting in New England as recently suggested by Harrison et al. [1989] is most likely pre-Mesozoic, and as mentioned above, published 


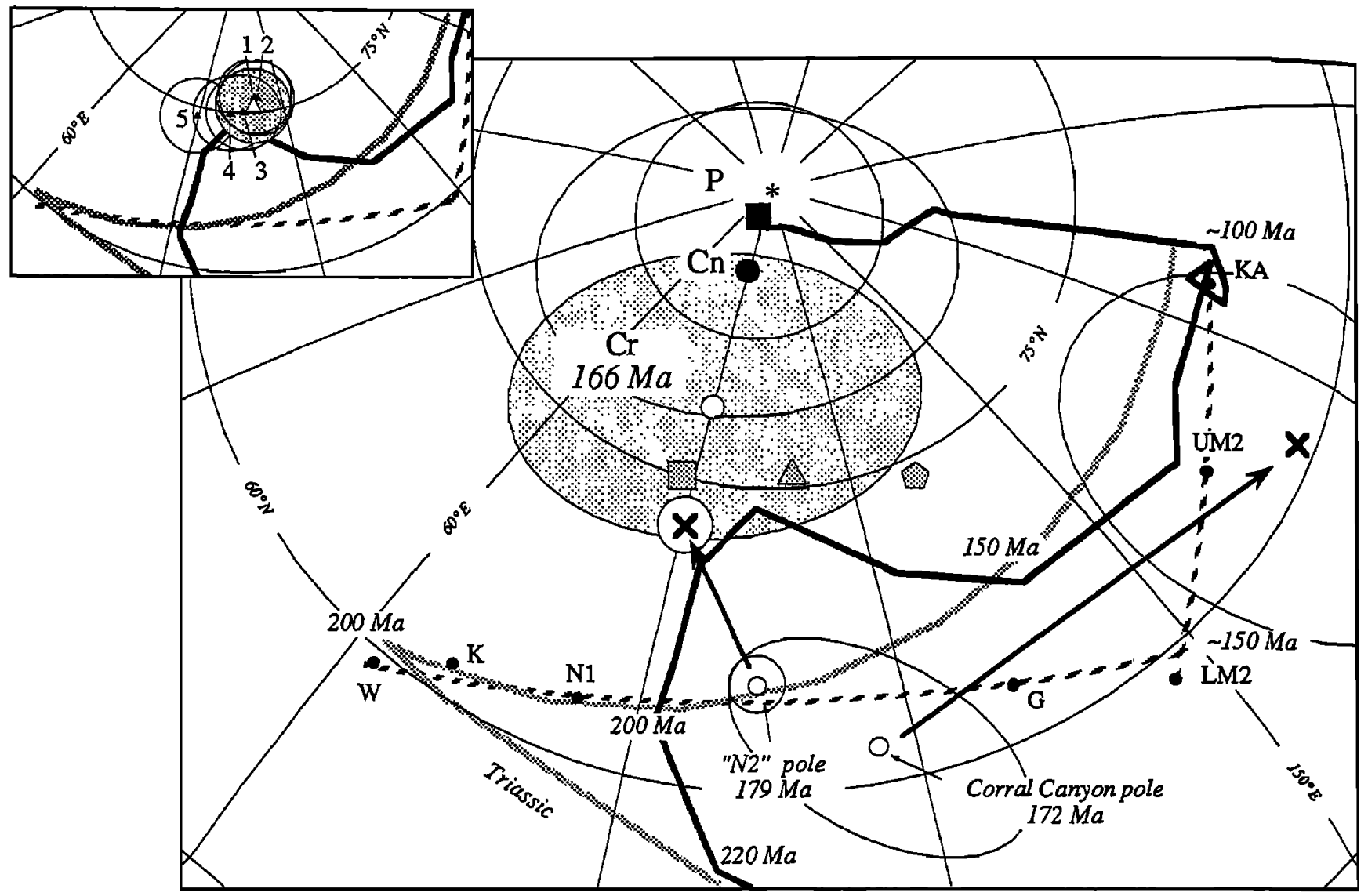

Fig. 8. The White Mountains $\mathrm{P}$ component (plutonic rocks), and reversed polarity $\mathrm{Cr}$ and nomal polarity $\mathrm{Cn}$ component (Moat volcanics) poles compared with North American apparent polar wander paths and published Jurassic reference poles (pole and apparent polar wander path abbreviations are the same as those in Figure 1). A mean Middle Jurassic pole transferred from the Gondwana continents using the Klitgord and Schouten [1986] Africa-North America reconstruction is shown by the triangle. The inset shows the limited range of possible locations of the Gondwana pole in North America coordinates using other published reconstructions (1, Bullard et al. [1965]; 2, LePichon et al. [1977]; 3, LePichon and Fox [1971]; 4, Lefort and Van der Voo [1981]; 5, Wissman and Reser [1982]). Reinterpretation of the N2 and Corral Canyon magnetizations as secondary and post-tilting suggests different locations of these poles (shown by the arrows) and can resolve the apparent discrepancy with the Middle Jurassic Moat volcanics Cr pole. High-latitude North American apparent polar wander during an even longer interval in the Jurassic is suggested by the mean Early Jurassic pole (square) and Late Jurassic pole (pentagon) for Europe transferred to North American coordinates using the reconstruction of Srivastava and Tapscont [1986] (see Table 4).

Cretaceous and Triassic paleomagnetic results tend to argue against post-Triassic regional tilt.

Indirect evidence that would seem to argue against a Middle Jurassic age for the $\mathrm{Cr}$ (and/or $\mathrm{Cn}$ ) component pole is the disagreement with what are taken to be the few reliable Middle Jurassic reference poles for North America in a recent PEP apparent polar wander analysis [May and Butler, 1986]. For example, even excluding the Moat volcanics $\mathrm{Cn}$ component, the $\mathrm{Cr}$ component pole falls $18.6^{\circ}$ of arc distance from the lower latitude Corral Canyon pole of May et al. [1986]. We attempted a test of our hypothesis that the apparent polar wander path for North America ventured to high latitudes during the Middle Jurassic, as suggested by the Moat $C$ component magnetization, by transferring Jurassic paleopoles from other continents.

\section{MIDDLE JURASSIC POLES FROM GONDWANA IN THE NORTH AMERICAN REFERENCE FRAME}

The Gondwana continents and Europe are potential sources of Middle Jurassic paleopoles which can be transferred to North
American coordinates according to reasonably well established reconstruction parameters. The Gondwana continents best represented by Middle Jurassic poles are Africa, (East) Antarctica, and Australia whereas, for example, Irving and Irving [1982] list just one Middle Jurassic pole for South America and only a single pole for the entire Jurassic of India. Reconstruction of Gondwana also provides an intermediate test of the consistency of the paleomagnetic data prior to transfer to the North American reference frame. For Europe there are hardly any Middle Jurassic poles regarded as reliable, however, recently published paleomagnetic studies of Lower and Upper Jurassic rocks provide broad constraints on the Middle Jurassic pole position.

Most of the available Jurassic poles from Africa would include the Middle Jurassic according to quoted ages and their uncertainties. Thus an average Jurassic pole calculated by Besse and Courtillot [1988] for rocks ranging in age from 150 to $209 \mathrm{Ma}\left(67.5^{\circ} \mathrm{N}, 254.4^{\circ} \mathrm{E}, A 95=5.5^{\circ}\right.$ for $N=6$ studies $)$ is not significantly different from a nominally Middle Jurassic pole (170 $\pm 15 \mathrm{Ma}$ ) calculated by Irving and Irving [1982] 
located at $62^{\circ} \mathrm{N}, 266^{\circ} \mathrm{E}$ ( $A 95=10^{\circ}$ for $N=8$ studies). In a subset of accepted African poles thought to be reliable by Besse and Courtillot but more restricted to the Middle Jurassic (163-187 Ma; DNAG geological time scale), three poles qualify: the Karoo dolerites (McElhinny and Jones [1965]; age is 150-165 Ma from Cox [1988]), the Zimbabwe MarangudziMateke Hills pole (Gough et al. [1964]; age is $186 \mathrm{Ma}$ from Cox [1988], and the Mauritania Hodh pole (Sichler et al. [1980]; age is $187 \mathrm{Ma}$ ). These three poles give a preferred meen Middle Jurassic African pole position located at $65.8^{\circ} \mathrm{N}$, $257.1^{\circ} \mathrm{E}\left(A_{95}=12.6^{\circ}\right)$, which is not significantly different from the Irving and Irving or Besse and Courtillot estimates.

For the (East) Antarctica Middle Jurassic pole position, we use the mean paleopole calculated by Grunow et al. [1987] based on 15 published studies of the Ferrar dolerites $\left(54.8^{\circ} \mathrm{N}\right.$, 40.3 $\mathrm{E}$; $A 95=3.9^{\circ}$; Table 4), with $\mathrm{K}-\mathrm{Ar}$ and $\mathrm{Ar}-\mathrm{Ar}$ ages ranging primarily from about $160 \mathrm{Ma}$ to $180 \mathrm{Ma}$ [Elliot et al., 1985]. A mean (north) pole calculated using results of just three Ferrar studies that reported reversed magnetizations [Blundell and Stevenson, 1959; Beck et al., 1979; Lovlie, 1979] is located at $56.2^{\circ} \mathrm{N}, 38.0^{\circ} \mathrm{E}\left(A 95=9.5^{\circ}\right)$ and is not significantly different than the mean of the remaining 12 normal polarity poles $\left(54.4^{\circ} \mathrm{N}, 40.8^{\circ} \mathrm{E} ; A 95=4.8^{\circ}\right)$. This antipodality test suggests that the Ferrar dolerites are, on the average, probably not biased by some unresolved contamination and should average secular variation because they have recorded at least one polarity reversal.

The Irving and Irving [1982] mean $170 \pm 15 \mathrm{Ma}$ paleopole for Australia $\left(47^{\circ} \mathrm{N}, 1^{\circ} \mathrm{E}\right)$ is based on three studies: the Kangaroo Island basalt [Schmidt, 1976a], the New South Wales intrusions [Schmidt, 1976b], and the Tasmanian dolerites [Schmidt and McDougall, 1977]. Because only two site means were used to determine the Kangaroo Island pole, we adopt the mean paleopole of Grunow et al. [1987] at $51.0^{\circ} \mathrm{N}$ and $0.5^{\circ} \mathrm{E}$, calculated using just the New South Wales intrusions and the Tasmanian dolerites data, and with a mean age of $172 \mathrm{Ma}$. The three reversed and three normal polarity site mean directions from the New South Wales intrusions are antipodal, and the mean age of the rocks studied is $174.5 \mathrm{Ma}$ The pole from the Tasmanian dolerites (170.5 Ma) was calculated by Schmidt and McDougall using 21 westerly site mean magnetization directions (all of normal polarity). A group of 12 normal polarity site means with a more easterly trend were considered anomalous by these authors.

As might be expected, the mean poles from Africa, East Antarctica, and Australia with these continents in their present positions grossly disagree ( $K=6.5$ for $N=3$ continents). However, when Gondwana is reassembled [Norton and Sclater, 1979], these Middle Jurassic poles agree very well with a mean located at $64.9^{\circ} \mathrm{N}, 260.3^{\circ} \mathrm{E}$ in African coordinates $(K=1242$, $A 95=3.5^{\circ}$, giving unit weight to each of the three continents, Table 4). If instead the Smith and Hallam [1970] Gondwana reconstruction is used, the Middle Jurassic mean pole $\left(64.2^{\circ} \mathrm{N}\right.$, $249.4^{\circ} \mathrm{E}, K=299, A 95=7.1^{\circ}$ ) is less well-defined, although not significantly different from the result obtained using the Norton and Sclater rotation parameters. Although we have not taken into account the effects of possible strain in the Benue trough [Pindell and Dewey, 1982; R. Hargraves, personal communication, 1990], the excellent agreement of pole positions following the reassembly of Gondwana, and the

TABLE 4. Paleomagnetic Pole Positions From Gondwana (Africa, Australia, East Antarctica) and Europe

\begin{tabular}{|c|c|c|c|c|c|c|c|c|c|c|c|}
\hline \multirow{2}{*}{ Pole Name } & \multirow[b]{2}{*}{ Sources } & \multirow[b]{2}{*}{ Age } & \multicolumn{2}{|c|}{ Pole } & \multirow[b]{2}{*}{$N$} & \multirow[b]{2}{*}{$\underline{K}$} & \multirow[b]{2}{*}{ A95 } & \multicolumn{2}{|c|}{ African Coordinates } & \multicolumn{2}{|c|}{ North American Coordinates } \\
\hline & & & NLatitude & E Longitude & & & & NLaritude & E Longitude & N Latitude & E Longitude \\
\hline \multicolumn{12}{|c|}{ Gondwana - Middle Jurassic } \\
\hline Africa.mJur & $1-3$ & $177 \mathrm{Ma}$ & 65.8 & 257.1 & 3 & 98 & 12.6 & 65.8 & 257.1 & - & _ \\
\hline Australia.mJur & 4,5 & $172 \mathrm{Ma}$ & 51.0 & 000.3 & 2 & 245 & - & 62.6 & 261.0 & - & - \\
\hline EastAnt.mJur & & $170 \mathrm{Ma}$ & 54.8 & 040.3 & 15 & 97 & 3.9 & 66.2 & 262.6 & - & - \\
\hline Mean & & $173 \mathrm{Ma}$ & - & -- & 3 & 1242 & 3.5 & 64.9 & 260.3 & 75.6 & 109.1 \\
\hline \multicolumn{12}{|c|}{ Europe - Early Jurassic } \\
\hline Juras Mt. & 7 & Oxf.-Kimm. & 77.7 & 148.4 & $24 *$ & 26 & 5.9 & - & -- & - & - \\
\hline Franconia & 8 & Oxf.-e.Kimm. & 68.0 & 130.0 & $79 * *$ & na & $(5.0)$ & - & - & - & - \\
\hline Poland & 9 & m.Call.-Oxford. & 72.3 & 150.4 & $9 *$ & 58 & (7.3) & - & - & - & - \\
\hline Mean & & $-159 \mathrm{Ma}$ & 72.7 & 141.6 & 3 & 193 & 8.9 & -- & - & 73.9 & 131.4 \\
\hline \multicolumn{12}{|c|}{ Europe - Late Jurassic } \\
\hline Paris Basin & 10 & Toarcian & 74.7 & 113.9 & $61 * *$ & 22 & (3.8) & - & - & - & - \\
\hline Paris Basin & 10 & Toarcian & 67.6 & 092.8 & $39 * *$ & 30 & (4.1) & - & - & - & - \\
\hline Normandy & 11 & Pliens-Toarc. & 70.4 & 109.5 & $6^{*}$ & 143 & 5.6 & - & - & - & - \\
\hline Mean & & $\sim 192 \mathrm{Ma}$ & 71.1 & 104.2 & 3 & 249 & 7.8 & - & - & 75.0 & 087.5 \\
\hline
\end{tabular}

Pole $\mathrm{N}$ latitude, $\mathrm{E}$ longitude, pole latitude and longitude in geographic coordinates; $N$, number of studies used; $K$, Fisher dispersion parameter; na, data not available; $A 95$, radius of $95 \%$ confidence about mean pole; $(\alpha 95)$, radius of $95 \%$ confidence about mean direction used in calculation of given pole; African coordinates, pole latitude and longitude rotated to the African reference frame using Norton and Sclater [1979]; Norh American coordinates, pole latiude and longitude rotated to the North American reference frame using Klitgord and Schouten [1986] for Gondwana (Africa): 66.97, 347.66, $\Omega=-74.57$, and Srivastava and Tapscott [1986] for Europe: 79.50, 151.92, $\Omega=-25.59$. Sources: (1) Gough et al. [1964]; (2) McElhinny and Jones [1965]; (3) Sichler et al. [1980]; (4) Schmidt and McDougall [1977]; (5) Schmidt [1976b]; (6) Grunow et al. [1987]; (7) Johnson et al. [1984]; (8) Heller [1977.1978]; (9) Kadzialko-Hofmokl and Kruczyk [1987]; (10)

Galbrun et al. [1988]; (11) Fabre [1986].

* number of sites.

** number of samples. 
positive outcome of the antipodality tests that were possible on the East Antarctica and Australian results, stand as firstorder evidence for the general reliability of the Gondwana reconstruction and Middle Jurassic poles.

The mean Middle Jurassic pole for Gondwana was transferred to North American coordinates according to six published sets of reconstruction parameters for Africa to North America [Klitgord and Schouten, 1986; Wissman and Reser, 1982; Lefort and Van der Voo, 1981; LePichon et al., 1977; LePichon and Fox, 1971; Bullard et al., 1965]. Variation in the location of the Gondwana pole subject to these different reconstruction parameters gives a sense of the uncertainty. The maximum separation between any two of the six possible locations of the transferred pole (inset Figure 8) occurs when one compares the positions using LePichon et al. [1977] and Wissman and Reser [1982] reconstruction parameters, however, this maximum separation amounts to only $5.8^{\circ}$. We regard as representative the location of the transferred Gondwana pole $\left(75.6^{\circ} \mathrm{N}\right.$, $109.1^{\circ} \mathrm{E}$ ) using the recent Klitgord and Schouten [1986] reconstruction.

\section{ASSESSMENT OF MIDDLE JURASSIC NORTH AMERICAN POLES}

We can now proceed to test the hypothesis that the North American apparent polar wander path ventured to high latitude during the Jurassic. The hypothesis that the Moat $\mathrm{Cr}$ component pole (presumed age $=166 \mathrm{Ma}$ ) and the transferred Gondwana Middle Jurassic pole (mean age $=173 \mathrm{Ma}$ ) share a common mean can not be rejected at the $95 \%$ confidence level (Figure 8). These two poles however are distinct from the lower latitude Newark Igneous Trend "N2" pole ( 179 Ma) and in particular the Corral Canyon pole (172 Ma) which have been accepted as reliable Middle Jurassic reference poles for North America in a recent analysis [May and Butler, 1986]. As described above, the general reliability of the mean Middle Jurassic Gondwana pole is indicated by its intemal consistency and moreover, among the six possible positions of the Gondwana pole in North American coordinates, most fall at latitudes of nominally $75^{\circ} \mathrm{N}, 10^{\circ}-15^{\circ}$ more northerly than the $\mathrm{N} 2$ and Corral Canyon pole positions. We therefore interpret the agreement between the transferred Gondwana pole and the Moat $\mathrm{Cr}$ component pole as strong supporting evidence for the migration of the North American apparent polar wander path to high latitudes in the Middle Jurassic, similar to that suggested by Irving and Irving [1982]. Implicit in this interpretation is that the N2 and Corral Canyon reference poles are somehow anomalous, and this naturally requires discussion. Although rapid apparent polar wander of about $1^{\circ}-2 \%$ m.y. could be invoked to explain the differences between the $\mathrm{Cr}$ pole and the $\mathrm{N} 2$ and Corral Canyon pole locations, we believe that a more plausible explanation is that the $\mathrm{N} 2$ and Corral Canyon magnetizations are in fact secondary, were acquired after tilting, and should therefore be considered in the geographic rather than tilt-corrected reference frame.

The N2 pole was calculated by Smith and Noltimier [1979] using paleomagnetic data from a number of published studies of intrusive rocks associated with Mesozoic rifting in eastern North America. This pole falls at $65.3^{\circ} \mathrm{N}, 103.2^{\circ} \mathrm{E}$, which is nearly $14^{\circ}$ of arc from, and $10^{\circ}$ more southerly than, the Moat volcanics Cr pole (Figure 8). Recently, Witte and Kent [1989] have found that Camian and Norian sedimentary rocks from the Newark Basin contain a pervasive normal polarity magnetization overprint (Newark Basin B component) with a niean direction similar to that reported for the "N2" intrusive rocks in common coordinates. This similarity and the lack of reported field tests led Witte and Kent to suggest that both the Newark Basin B component overprint and N2 intrusive magnetizations were secondary in origin, being perhaps related to the proposed Middle Jurassic $(-175 \mathrm{Ma})$ hydrothermal event that reset radiometric ages of many igneous intrusions in the Newark Supergroup basins [Sutter, 1988]. In the in sin reference frame, considered appropriate on the basis of a negative fold test [Witte et al., 1989], the Newark Basin B component overprint pole of Witte and Kent [1989] falls at $72.7^{\circ} \mathrm{N}, 89.8^{\circ} \mathrm{E}\left(A 95=3.4^{\circ}\right)$ and is indistinguishable from the Moat volcanics $\mathrm{Cr}$ pole at $95 \%$ confidence (Figure 8 ).

The Corral Canyon pole from Jurassic volcanic rocks in the Patagonia Mountains, southern Arizona [May et al., 1986] falls at $61.8^{\circ} \mathrm{N}, 116.0^{\circ} \mathrm{E}$, nearly $19^{\circ}$ from the $\mathrm{Cr}$ component pole. The Corral pole position was calculated using tiltcorrected magnetization directions, but the decrease in directional scatter upon restoration of paleohorizontal is significant at only $75 \%$ confidence. If calculated without tilt correction, the Corral Canyon pole position $\left(61.2^{\circ} \mathrm{N}, 172.6^{\circ} \mathrm{E}\right)$ falls near younger (Cretaceous) North American poles (Figure 8), suggesting the possibility that the Corral Canyon tuffs have been remagnetized. This hypothesis is not precluded by the fold test statistics nor by the reported Rb-Sr whole rock age dating, a method not very sensitive to thermal resetting. Moreover, remagnetization may be just one expression of various episodes of tectonic activity to which the southem Basin and Range has been subjected since the Late Cretaceous. In this regard, Hagstrum and Sawyer [1989] found evidence for $-42^{\circ}$ of post-Cretaceous clockwise rotation in a paleomagnetic study of Late Cretaceous volcanic rocks in the Silver Bell Mountains of southern Arizona. May and Butler [1987] attributed what they regarded as enigmatic paleomagnetic results from Middle Jurassic volcanic rocks in the Canelo Hills, about $20 \mathrm{~km}$ northeast of the Patagonia Mountains, to Jurassic nondipole field behavior. However, the streaked pattern of site mean directions could also be due to some combination of remagnetization and tectonic rotations.

\section{DisCUSSION AND CONCLUSIONS}

To summarize briefly our findings, a high unblocking temperature magnetization of reversed polarity from the Moat volcanics in New Hampshire yields what we regard as a reliable Middle Jurassic pole from the White Mountains Magma Series. This $\mathrm{Cr}$ component pole falls at $78.7^{\circ} \mathrm{N}, 90.3^{\circ} \mathrm{E}$, a high-latitude position supported by the Newark Basin remagnetization (B) pole of Witte and Kent [1989]. These poles suggest an interval of high latitude apparent polar wander from $175 \mathrm{Ma}$ (Newark Basin B pole) to $\sim 166 \mathrm{Ma}$ (Moat volcanics $\mathrm{Cr}$ pole), a period of about 9 m.y. spanning the Bathonian and part of the Callovian ages (DNAG time scale). The discrepant Corral Canyon pole which falls in this interval $(172 \mathrm{Ma})$, regarded as reliable by May and Butler [1986], can be reinterpreted as having been remagnetized in the Cretaceous; the Newark Trend N2 igneous pole [Smith and Noltimier, 1979] is most probably also a secondary magnetization pole which, as the work of Witte and Kent [1989] suggests, may have been acquired in situ yielding a high-latitude pole position similar to the Newark Basin B pole. A mean pole (173 $\mathrm{Ma}$ ) transferred from Gondwana independently points to a high-latitude Middle Jurassic North American pole position, now documented directly by the Moat 
volcanics results and by the Newark Basin B pole even though these represent secondary magnetizations.

The arguments for a high-latitude Middle Jurassic pole position presented in this study will require reconsideration of the North American apparent polar wander path for the entire Jurassic. Indications already are that high-latitude apparent polar wander may have extended beyond the nominal age range of 166-175 Ma documented here. Recently available Early Jurassic (Pliensbachian-Toarcian $\sim 190 \mathrm{Ma}$ ) poles from Europe fall at latizudes of about $72^{\circ}-78^{\circ}$ in North American coordinates according to available plate reconstructions (Table 4) and imply a rapid apparent polar wander shift from the SinernurianPliensbachian ( 195 Ma) North American "cusp" poles located at about $60^{\circ} \mathrm{N}, 60^{\circ} \mathrm{E}$ (Figure 8). Based on paleomagnetic results from Oxfordian-Kimmeridgian limestones with a positive fold test Johnson et al. [1984] have confirmed a high latitude pole position for the Late Jurassic of Europe, in agreement with several other published Oxfordian-Kimmeridgian poles from stable Europe which retain high latitude in the North American reference frame (Table 4 and Figure 8). The disparity of these transferred European poles with some latest Kimmeridgian to Tithonian North American reference poles (e.g., Glance conglomerate pole, $151 \mathrm{Ma}$ from Kluth et al. [1982]; and lower and upper Morrison Formation poles from Steiner and Helsley, [1975]), regarded as reliable by May and Butler [1986], similarly raises questions, beyond the scope of this paper, concerning either rapid apparent polar wander or problems in general with the Late Jurassic reference poles.

Clearly, additional paleomagnetic studies of rocks from North America are needed to test the evidence of a high latinde Middle Jurassic pole presented in this study. Furthermore, such empirical testing of the North American apparent polar wander path may be required for most of the Jurassic. With regard to PEP analysis, May and Butler [1986] have divided the original 100-m.y.-Iong Jurassic-Cretaceous small-circle track of Gordon et al. [1984] into two small-circle segments, each about $50 \mathrm{~m} . y$. long. A high-latitude Middle Jurassic pole position indicated by the Moat volcanics data takes this segmentation process one step further, implying that at least the Jurassic portion of the apparent polar wander path may be composed of yet shorter ( $-30 \mathrm{~m} . \mathrm{y}$.) segments. We suspect it will take considerable amounts of high precision data to allow the determination of well-constrained small-circle tracks (and corresponding Euler poles) given such short path segments of apparent polar wander.

Acknowledgments. The authors would like to thank R. Hargraves and two anonymous reviewers for their comments. Bill Witte, Paul Olsen, Steve Cande, and Neil Opdyke are likewise acknowledged for their advice and support. Funding for this study was provided by the National Science Foundation, Earth Sciences Division (grant EAR8803814) and the Geological Society of America (research grant 389687). This is Lamont-Doherty Geological Observatory contribution 4663 .

\section{REFERENCES}

Aldrich, L. T., G. W. Wetherill, G. L. Davis, and G. R. Tilton, Radioactive ages of micas from granitic rocks by Rb-Sr and K-Ar methods, Eos Trans. AGU, 39, 1124-1134, 1958.

Beck, M. E., Jr., R. F. Burmester, and S. D. Sheriff, Field reversal and paleomagnetic pole for Jurassic Antarctica (abstract), Eos Trans. $A G U, 60,818,1979$.

Besse, J., and V. Courtillot, Paleogeographic maps of the continents bordering the Indian Ocean since the Early Jurassic, J. Geophys. Res., 93, 11.791-11,808, 1988.
Billings, M. P., The petrology of the North Conway quadrangle in the White Mountains of New Hampshire, Proc. Am. Acad. Arts Sci., 63, 67-137, 1928.

Billings, M. P., The Geology of New Hampshire, part II,-Bedrock Geology, 203 pp., New Hampshire Planning Development Commission Mining Resource Survey, Concord, 1956.

Blundell, D. J., and P. J. Stevenson, Paleomagnetism of some dolerite intrusions from the Theron Mountains and Whichaway Nunataks, Antarctica, Nature, 184, 1860, 1959.

Bullard, E. C., J. E. Everett, and A. G. Smith, The fit of the continents around the Atlantic, Symposium on Continental Drift, Philos. Trans. R. Soc. London, Ser. A, 258, 41-51, 1965.

Chapman, C. A., A comparison of the Maine coastal complexes and the magmatic central complexes of New Hampshire, in Studies of Appalachion Geology: Northern and Maritime, edited by E. Zen et al., pp. 385-398, Interscience, New York, 1968.

Cox, K. G., The Karoo Province, in Continental Flood Basalts, edited by J. D. Macdougall, pp. 239-271, Kluwer Academic, Boston, Mass., 1988.

Doherty. J. T., and J. B. Lyons, Mesozoic erosion rates in northem New England, Geol. Soc. Am. Bull., 91, 16-20, 1980.

Eby, G. N., and J. W. Creasy, Strontium and lead isotope geology of the Jurassic White Mountain batholith, New Hampshire, Geol. Soc. Am. Abstr. Programs, 15, 188, 1983.

Elliot, D. H., R. J. Fleck, and J. F. Sutter, Potassium-argon age determinations of Ferrar Group rocks, central Transantarctic Mountains, in Geology of the Central Transantarctic Mountains, Antarct. Res. Ser., vol. 36, edited by M. D. Tumer and J. F. Splettstoesser, pp. 197-224, AGU, Washington, D.C., 1985.

Fabre, A., Le temps dans la construction des courbes de dérive apparente du pôle paléomagnétique: Application à 1'Europe du Permien au Jurassique, Ph.D. dissertation, Univ. Bretagne Occidentale, Brest, France, 1986.

Fisher, R. A., Dispersion on a sphere, Proc. R. Soc. London, Ser. A, $217,295-305,1953$.

Fitzgerald, J. P., and J. W. Creasy, The Moat Volcanics, Moat Range, NH: An intra-caldera setting, Geol. Soc. Am. Abstr. Programs, 20 $18,1988$.

Foland, K. A., and H. Faul, Ages of the White Mountain intrusivesNew Hampshire, Vermont and Maine, USA, Am. J. Sci., 277, 888904, 1977.

Foland, K. A., A. W. Quinn, and B. J. Gileuti, K-Ar and Rb-Sr Jurassic and Cretaceous ages for intrusives of the White Mountain Magma Series, Am. J. Sci., 270, 321-330, 1971.

Galbrun, B., J. Gabilly, and L. Rasplus, Magnetostratigraphy of the Toarcian stratotype sections at Thouars and Airvault (Deux-SÉvres, France), Earth Planet. Sci. Lett., 87, 453-462, 1988.

Gordon, R. G., A. Cox, and S. O'Hare, Paleomagnetic Euler poles and the apparent polar wander and absolute motion of North America since the Carboniferous, Tectonics, 3, 499-537, 1984.

Gough, D. I., A. Brock, D. L. Jones, and N. D. Opdyke, The paleomagnetism of ring complexes at Baranguzi and the Mateke Hills, J. Geophys. Res., 69, 2499-2507, 1964.

Grunow, A. M., I. W. D. Dalziel, and D. V. Kent, Ellsworth-Whitmore Mountains crustal block, westem Antarctica: New paleomagnetic results and their tectonic significance, in Gondwane Six: Structure, Tectonics, and Geophysics, Geophys. Monogr. Ser., vol. 41, edited by G. D. McKenzie, 109-116, AGU, Washington. D.C., 1987.

Hagstrum, J. T., and D. A. Sawyer, Late Cretaceous paleomagnetism and clockwise rotation of the Silver Bell Mountains, south central Arizona, J. Geophys. Res., 94, 17,847-17,860, 1989.

Harrison, T. M., F. S. Spear, and M. T. Heizler, Geochronologic studies in central New England II: Post-Acadian hinged and differential uplift, Geology, 17, 185-189, 1989.

Heller, F., Paleomagnetism of Upper Jurassic limestones from southem Germany, J. Geophys., 42, 475-488, 1977.

Heller, F., Rockmagnetic studies of Upper Jurassic limestones from southern Germany, J. Geophys., 44, 525-543, 1978.

Hurley, P. M., H. W. Fairbairn, W. H. Pinson, and G. Faure, K-Ar and $\mathrm{Rb}-\mathrm{Sr}$ minimum ages for the Pennsylvania section in the Narragansett Basin, Geochim. Cosmochim. Acta, 18, 247-258, 1960 .

Irving, E., and G. A. Irving, Apparent polar wander paths Carboniferous through Cenozoic and the assembly of Gondwana, Geophys. Swrv., 5, 141-188, 1982.

Johnson, R. J. R., R. Van der Voo, and W. Lowrie, Paleomagnetism and late diagenesis of Jurassic carbonates from the Jura Mountains, 
Switzerland and France, Geol. Soc, Am. Bull, 95, 478-488, 1984.

Kadzialko-Hofmokl, M., and J. Kruczyk, Paleomagnetism of middlelate Jurassic sediments from Poland and implications for the polarity of the geomagnetic field, Tectonophysics, 139, 53-66, 1987.

Kirschvink, J. L., The least-squares line and plane and the analysis of paleomagnetic data, Geophys. J. R. Astron. Soc., 62, 699-718, 1980.

Klitgord, K. D., and H. Schouten, Plate kinematics of the central Allantic, in The Geology of North America, vol. M. The Western North Atlantic Region, edited by P. R. Vogt and B. E. Tucholke, pp. 351-378, Geological Society of America, Boulder, Colo., 1986.

Kluth, C. F., R. F. Butler, L. E. Harding, M. Shafiqullah, and P. E. Damon, Paleomagnetism of Late Jurassic rocks in the northern Canelo Hills, southesstem Arizona, J. Geophys. Res., 87, 70797086, 1982.

Lefort, J.-P., and R. Van der Voo, A kinematic model for the collision and complete suturing between Gondwanaland and Laurasia in the Carboniferous, J. Geol., 89, 537-550, 1981.

LePichon, X., and J. P. Fox, Marginal offsets, fracture zones, and the early opening of the North Atlantic, J. Geophys. Res., 76, 6294$6308,1971$.

LePichon, X., J.-C. Sibuet, and J. Franchteau, The fit of the continents around the North Atlantic Ocean, Tectonophysics, 38, 169-209, 1977.

Lovlie, R., Mesozoic paleomagnetism in Vestfjella, Dronning Maud Land, East Antarctica, Geophys. J. R. Astron. Soc., 59, 529-537, 1979.

Mankinen, E. A., Paleomagnetic evidence for a Late Cretaceous deformation of the Great Valley sequence, Sacramento Valley, Califomia, J. Res. U.S. Geol. Surv., 6, 383-390, 1978.

May, S. R., and R. F. Butler, North American Jurassic apparent polar wander, implications for plate motion, paleogeography and Cordilleran tectonics, J. Geophys. Res., 91, 11,519-11,544, 1986.

May, S. R., and R. F. Butler, Paleomagnetism of the Jurassic Canelo Hills Volcanics, southeastem Arizona, Ariz. Geol. Soc. Dig., 18, 121-137, 1987.

May, S. R., R. F. Butler, M. Shafiqullah, and P. E. Damon, Paleomagnetism of Jurassic rocks in the Patagonia Mountains, southeastern Arizona: Implications for the North American $170 \mathrm{Ma}$ reference pole, J. Geophys. Res., 91, 11,545-11,555, 1986.

McElhinny, M. W., and D. L. Jones, Paleomagnetic measurements on some Karoo dolerites from Rhodesia, Nature, 206, 921-922, 1965.

McFadden, P. L., and F. J. Lowes, The discrimination of mean directions drawn from Fisher distributions, Geophys. J. R. Astron. Soc., 67, 19-33, 1981.

Norton, I. O., and J. G. Sclater, A model for the evolution of the Indian Ocean and the breakup of Gondwanaland, J. Geophys. Res., 84, 6803-6830, 1979.

Opdyke, N. D., and H. Wensink, Paleomagnetism of rocks from the White Mountain plutonic-volcanic series in New Hampshire and Vermont, J. Geophys. Res., 71, 3045-3051, 1966.

Palmer, A. R., The decade of Norh American Geology 1983 geologic timescale, Geology, 11, 503-504, 1983.

Pindell, J., and J. F. Dewey, Permo-Triassic reconstruction of westem Pangea and the evolution of the Gulf of Mexico/Caribbean region, Tectonics, 1, 179-211, 1982.

Reeve, S. C., Paleomagnetic studies of sedimentary rocks of Cambrian and Triassic age, Ph.D. dissertation, Richardson, Univ. of Tex. at Dallas, 426 pp., 1975.

Schmidt, P. W., A new paleomagnetic investigation of Mesozoic igneous rocks in Australia, Tectonophysics, 33, 1-13, 1976a.

Schmidt, P. W., The non-uniqueness of the Australian Mesozoic paleomagnetic pole position, Geophys. J. R. Astron. Soc., 47, $285-300,1976 b$.
Schmidt, P. W., and I. McDougall, Paleomagnetic and potassiumargon dating studies of the Tasmanian dolerites, Aust. J. Earth Sci. 25(6), 321-328, 1977.

Sclater, J. G., S. Hellinger, and C. Tapscott, The paleobathymetry of the Atlantic Ocean from the Jurassic to the present, J. Geol., 85 , 509-552, 1977.

Sichler, B., J. L. Olivet, J. M. Auzende, H. Jonquet, J. Bonnin, and A Bonifay, Mobility of Marocco, Can. J. Earth Sci., 17, 1546-1588, 1980.

Smith, A. G., and A. Hallam, The fit of the southern continents, Nature, 225, 139-144, 1970.

Smith, T. E., and H. C. Noltimier, Paleomagnetism of the Newark trend igneous rocks of the north central Appalachians and the opening of the central Atlantic Ocean, Am. J. Sci., 279, 778-807, 1979.

Srivastava, S. P., and C. R. Tapscott, Plate kinematics of the North Atlantic, in The Geology of North America, vol. M, The Western North Atlontic Region, edited by P. R. Vogt and B. E. Tucholke, pp 379-404, Geological Society of America, Boulder, Colo., 1986.

Steiner, M. B., and C. E. Helsley, Magnetic polarity sequence of the Upper Triassic Kayenta Formation, Geology, 2, 191-194, 1974.

Steiner, M. B., and C. E. Helsley, Reversal pattern and apparent polar wander for the Late Jurassic, Geol. Soc. Am. Bull., 86, 1537-1543, 1975.

Steiner, M., J. Ogg, and J. Sandoval, Jurassic magnetostratigraphy, 3, Bathonian-Bajocian of Carcabuey, Sierra Harana and Canpillo de Arenas (Subbetic Cordillera, southem Spain), Earth Planet. Sci. Lett., 82, 357-372, 1987.

Sutter, J. F., Innovative approaches to the dating of igneous events in the early Mesozoic basins of the eastern United States, Studies of the Early Mesozoic Basins of the Eastern United States, edited by A J. Froelich and G. R. Robinson, U.S. Geol. Surv. Bull., 1776, 194200,1988 .

Tilton, G. R., G. L. Davis, G. W. Wetherill, and L. T. Aldrich, Isotopic ages of zircons from granites and pegmatites, Eos Trans. AGU, 38 , 360-371, 1957.

Van Fossen, M. C., and D. V. Kent, New paleomagnetic results from Jurassic and Cretaceous White Mountains igneous rocks of New England, EOS Trans. AGU, 68, 342, 1988.

Wissman, G., and H. A. Reser, A magnetic and halokinetic structural Pangea fit of northwest Africa and North America, Geol. Jahrb., 23, 43-61, 1982.

Witte, W. K., and D. V. Kent, A middle Camian to early Norian ( -225 Ma) paleopole from sediments of the Newark Basin, Pennsylvania Geol. Soc. Am. Bull., 101, 1118-1126, 1989.

Witte, W. K., D. V. Kent, and P. E. Olsen. Pre- and postfolding magnetizations of the Late Triassic Passaic formation sediments in southeast Pennsylvania, Geol. Soc. Am. Abstr. Programs, 21, 76, 1989.

Wu, F., and R. Van der Voo, Paleomagnetism of Middle-Late Triassic plutons in southem Maine, Tectonophysics, 156, 51-58, 1988.

Zijderveld, J. D. A., A.C. demagnetization of rocks: Analysis of results, in Methods in Paleomagnetism, edited by D. W. Collinson, K. M. Creer, and S. K. Runcom, pp. 245-286, Elsevier, New York, 1967.

Zimmerman, R. A., G. M. Reimer, K. A. Foland, and H. Faul, Cretaceous fission track dates of apatites from northern New England, Earth Planet. Sci. Lett., 28, 181-188, 1975.

D. V. Kent and M. C. Van Fossen, Lamont-Doherty Geological Observatory and Department of Geological Sciences, Columbia University, Palisades, NY 10964.

(Received March 14, 1990; revised June 6, 1990; accepted June 15, 1990.) 